\title{
Demokrasi Bağlamında Son Dönem Türk Sinemasına Bir Bakış: Tepenin Ardı ve Çoğunluk Film Örnekleri
}

\author{
An Examination of Recent Turkish Cinema in the Context of Democracy: Behind the \\ Hill and Majority Film Examples
}

\author{
Semih GÖNCÜ* \\ Süikrü SİM ${ }^{* *}$
}

\begin{abstract}
Öz
İletişim çalışmaları ile ilgili literatüre kısa bir göz gezdirildiğinde medya ve demokrasi bağlamında birçok çalışmanın yapıldığı görülecektir. Ne var ki sinema ile ilgili literatüre bakıldığında, sinema ve demokrasi ilişkisi henüz yeterince araştırılmamış bir alan olarak karşımıza çıkmaktadır. Konu ile ilgili Türkçe literatürde şu ana kadar yapılmış en geniş çalışma, Oğuz Onaran, Nilgün Abisel, Levent Köker ve Eser Köker’in gerçekleştirdiği Türk Sinemasında Demokrasi Kavramının Gelişmesi (1994) isimli çalışmadır. Söz konusu çalışmada sinemada yaratılan kurmaca dünyalarda demokratik süreçlerin işleyip işlemediği araştırılmıştır. Bu alanda yeterince araştırma yapılmadığı probleminden yola çıkan bu çalışma, yakın dönem Türk sinemasını, sinema ve demokrasi çerçevesinde irdelemeyi amaçlamaktadır. Çalışmada son dönem Türk Sinemasında gerek akademik araştırmalarda gerekse eleştirel yazılarda ön plana çıktığını varsaydığımız Çoğunluk (Seren Yüce, 2010) ve Tepenin Ardı (Emin Alper, 2012) filmleri demokrasi bağlamında incelenecektir. Çalışmanın kuramsal çerçevesini, Onaran, Abisel, Köker ve Köker’in (1994) filmleri demokrasi bağlamında irdelemek için geliştirdikleri yaklaşım oluşturmaktadır. Filmler metin analizine tabi tutularak sonuca ulaşılmaya çalışılmıştır. Her iki filmin de modern demokrasinin ön gördüğü niteliklerden uzak olduğu, ancak antik demokrasinin savunduğu niteliklere sahip olduğu tespit edilmiştir.
\end{abstract}

Anahtar Kelimeler: Türk Sineması, Demokrasi, Demokrasi ve Sinema, Tepenin Ardı, Çoğunluk

\section{Abstract}

When we review the literature regarding communication studies, there are many studies which features media and democracy as a context. However when we focus on film studies concerning the

* Doktora Öğrencisi, İstanbul Üniversitesi, İletişim Fakültesi, İstanbul, Türkiye, sgoncu38@gmail.com.

* Doç. Dr., İstanbul Üniversitesi, İletişim Fakültesi, İstanbul, Türkiye, sukrisim@istanbul.edu.tr. 
relationship between cinema and democracy, there are not many comprehensive studies. The most extended and comprehensive study about this matter is Evolvement of Democracy Notion in Turkish Cinema (Türk Sinemasında Demokrasi Kavramının Gelişmesi) authored by Oğuz Onaran, Nilgün Abisel, Levent Köker and Eser Köker in 1994. Aforementioned study investigates the effectiveness of democracy and democratic process in fictional universe which has been created by film makers. This study applies this point of view to research Turkish Cinema in the context of democracy. This article focuses on two recent movies Çoğunluk/Majority (Seren Yüce, 2010) and Tepenin Ardr/ Behind the Hill (Emin Alper, 2012); which are films that have been subjected to many articles in both academic and non-academic writing. As the theoretical framework, this study uses the same approach which has been used by Onaran, Abisel, Köker and Köker (1994) to investigate the films in the context of democracy. In order to analyze the films, textual analysis has been applied. It has been determined that both films do not have the qualities predicted by modern democracy, but possess the qualities which antique democracy defends.

Keywords: Turkish Cinema, Democracy, Democracy and Cinema, Behind The Hill, Majority

\section{Giriş}

İletişim çalışmalarıyla ilgili literatüre kısa bir göz gezdirildiğinde medya ve demokrasi bağlamında birçok çalışmanın yapıldığı görülecektir (Atabek, 2002; Aytekin ve Sütcü, 2013; Cereci, 2013; Chomsky, 1993; Işık, 2005; Keane, 2013). Ne var ki, sinema ile ilgili literatüre bakıldığında sinema ve demokrasi bağlamı henüz yeterince araştırılmamış bir alanı teşkil etmektedir. Filmlerin günümüz dünyasında yarattığı etki ve birçok kavramla kurulan ilişkisi düşünüldüğünde, demokrasi ve sinema ilişkisinin yeterince araştırılmadığını görmek ilginçtir. Zira filmler gerek toplumu gerekse kişileri temsil etmek (inşa etmek) anlamında büyük bir öneme sahiptir. Michael Ryan ve Douglas Kellner'in (2010) ifadesiyle “[f]ilmler, herhangi bir durumu yansıtmaktan çok, o durumun tasarlanan belli bir biçimini oluşturmak üzere seçilmiş ve birleştirilmiş temsili öğeler yoluyla birtakım tezler ileri sürer, bunu yaparken, seyirciye belli bir konumu ya da bakış açısını telkin ederler" (s. 18). Dolayısıyla filmlerde işlenen konular, gözlenen hadiseler filmler hangi ülkeye ait ise o ülkenin düşünce iklimi ve yaşam biçimiyle doğrudan ilişkilidir. Çünkü yaşama dair istekler, öneriler, karşı çıkışlar, hatta yaşamın örgütlenişi de dahil olmak üzere, kendine has bir şekilde sinemasal dünyayı inşa etmektedir (Onaran, Abisel, Köker ve Köker, 1994, s. xii). Bu düsturdan yola çıkan Oğuz Onaran, Nilgün Abisel, Levent Köker ve Eser Köker, sinemada yaratılan kurmaca dünyalarda demokratik süreçlerin işleyip işlemediğini incelemek için Türk Sinemasında Demokrasi Kavramının Gelişmesi (1994) isimli çalışmaya imza atmışlardır. İleriki sayfalarda detaylı bir şekilde açıklanacak olmakla birlikte Onaran, Abisel, Köker ve Köker (1994), filmleri demokrasi bağlamında ele alırken antik ve modern demokrasi teorilerinden yararlanmış ve filmlerde kurulan kurmaca evrenlerde ne tür bir demokrasinin tasarlandığını tespit etmeye çalışmıştır. Gelinen nokta itibariyle bu çalışma, günümüzde dahi sinema ve demokrasi bağlamında ön plana çıkan kapsamlı bir çalışmadır. Ne var ki, bu konunun sözü edilen araştırmacılar haricinde yeterince irdelenmediği de görülmektedir. $\mathrm{Bu}$ 
sebeple çalışmamız, sinema ve demokrasi ilişkisini anlamaya yönelik alana bir katkı sunmayı amaçlamaktadır. Çalışmada, son dönem Türk sinemasında, gerek akademik yazılarda gerekse eleştirilerde ön plana çıktı̆̆ını varsaydığımız, Çoğunluk (Seren Yüce, 2010) ve Tepenin Ardı (Emin Alper, 2012) filmleri demokrasi bağlamında incelenecektir. Bu filmlerin seçilme sebeplerindeki temel nokta, Onaran, Abisel, Köker ve Köker'in (1994) film seçimindeki yaklaşımlarının etkisidir. Araştırmacılar film seçiminde pratik bir başlangıç sunması açısından üç farklı ölçüt belirlemişlerdir: Filmin popülerliği, yoğun eleştirel ilgi görmesi ve siyasal-toplumsal bir konuyu işlemiş olması (s. xvi). Çalışmamızda seçilen filmlerin ana akım sinema içerisinde yer alan popüler örnekler oldukları söylenemez. Fakat filmlerin gerek akademi gerekse film eleştirmenleri tarafından yoğun bir şekilde eleştirel ilgiye tabi tutuldukları, ileride değinileceği üzere, aşikardır. Üstelik, siyasal-toplumsal konuları da işledikleri açıktır.

Her iki filmde de kurulan yapıda demokrasi olgusunun nasıl bir şekilde oluştuğu incelenmeye çalışılacaktır. Bu şekilde, son dönem Türk sinemasında yer alan filmlerde kişiler ve toplum üzerinden tasarlanan demokratik yapının anlaşılacağı düşünülmektedir. Bunun yanında, demokratik yapının hangi tür demokrasiye (antik ya da modern) ait olduğu sorgulanırken, filmin demokratik anlamda eleştirel bir tutum sunup sunmadığı da irdelenecektir. Çalışmamızdaki kuramsal yaklaşım, ileriki sayfalarda ayrıntılı bir şekilde açıklanacak olan, Onaran, Abisel, Köker ve Köker'in (1994) filmleri demokrasi bağlamında incelemek için geliştirdikleri yaklaşımdır. Araştırmacılar, bu yaklaşımı kullanırken filmleri birer metin olarak ele alarak çözümlemişlerdir. $\mathrm{Bu}$ çalışmada da filmler birer metin olarak değerlendirilmiş ve metin analizi uygulanmaya çalışılmıştır. ${ }^{1}$

Çoğunluk burjuva üst-orta sinıfta yer alan bir ailede yetişen Mertkan’n hikayesini anlatırken, Tepenin Ardı bir ailenin bir çiftlikte yaşadıklarıyla birlikte Yörüklerle çatışmalarını konu almaktadır. Her iki filmde de çok katmanlı ve farklı okumalara kapı aralayan bir yapı sunulmaktadır. Nitekim, iki film de yukarıda değinildiği gibi çeşitli akademik çalışmalara ve eleştirilere konu olmuştur. Örneğin, akademik olarak Kemal Deniz ve Zuhal Akmeşe (2015) Çoğunluk filmini toplumsal eşitsizliğin temsili bağlamında irdeler. Gül Yaşartürk (2014) filmi çekirdek aile kavramı etrafında, Fırat Sayıcı (2011) gerçekçilik bağlamında, Ahmet Oktan ve Kevser Akyol (2016) ise baba-oğul ilişkisi çerçevesinde incelerler. Keza Eren Yüksel de (2013) filmdeki baba-oğul ilişkisini erkeklik kriziyle birlikte ele almıştır. Benzer şekilde, Tepenin Ardı üzerine de akademik çalışmalar yapılmıştır. Mesela, Ayşegül Gündoğdu (2014) filmi ötekilik, varoluş, gerçek ve fantezi kavramları çerçevesinde incelemiştir. Aslı Gön ise (2014) homososyallik, erkeklik ve aile kavramlarının ön planda olduğu bir inceleme gerçekleştirmiştir.

1 Bu noktada kısaca metin analizini açıklamak yerinde olacaktır. Alan McKee’ye (2003) göre anlam çıartılabilen her şey bir metindir. Metin analizi, gerek kültürel çalışmalarda gerekse film çalışmalarında kullanılan bir yöntemdir. Metin analizi film, televizyon programı, dergi gibi medya ürünlerini metin olarak ele alır ve bu doğrultuda bir analiz imkanı sunar. Metin analizi ele alınan metnin geçtiği kültüre ve zamana göre bir çeşit anlamlandırma çabasıdır, yani yorumlanmasıdır (s. 1-4). Metin analizinin bir metni yorumlama pratiği olduğunun altını çizen İrfan Erdoğana (2012) göre metin analizi uygulanırken anlamlı ve önemli olanın ne olduğuna karar verip seçmek gerekmektedir. Metin analizinde irdelenen nokta metnin muhtevasına yüklenmiş anlamın sosyal ve toplumsal anlamıdır. Metinden anlam çıkartabilmek için dikkat edilmesi gereken nokta ise metnin bağlamıdır. Örneğin metnin tarihsel, toplumsal veya ideolojik bağlamlarına dikkat edilmelidir (s. 149-152). Dolayısıyla çalışmada bağlamımız demokrasi kavramıdır. 
Akademik çalışmalar haricinde her iki filmi de farklı okumalara tabi tutan ciddi film eleştirileri kaleme alınmıştır. Örneğin, Tepenin Ardı filmine ulus, şiddet, iktidar, ötekilik, mekan, paranoya, kötülük vb. gibi çeşitli kavramlarla farklı okumalar yapılmıştır (Büte, 2013; Çağlıyan, 2014; Çiftçi, 2012; Konuşlu, 2013). Keza Çoğunluk filmi de; erkeklik, aile, ötekilik, iktidar, öznellik, faşizm, milliyetçilik vb. (Ahıska, 2012; Karakaşl1, 2012; Susam, 2014; Thwaites, 2012) gibi farklı bağlamlarda analiz edilmiştir.

Kısacası, her iki filmin de farklı okumalara açı olması söz konusudur. Bu durum, her iki filmi de demokrasi bağlamında incelemeyi uygun bir vaziyete getirmektedir. Dolayısıyla seçilen filmler Onaran, Abisel, Köker ve Köker'in (1994) film seçme yaklaşımına uygunluk göstermektedir. Filmleri incelemeye başlamadan önce demokrasi ve sinema bağlamına değinilerek, Onaran ve arkadaşlarının yaklaşımı detaylı bir şekilde açıklanmaya çalışılacaktır.

\section{Demokrasi Kavramı}

Demokrasi, antik bir sözcük olmakla birlikte, anlam yapısı her daim karmaşık olan bir kavram olmuştur. Kelime etimolojik olarak Yunanca; demos (halk) ve kratos (yönetim) kök sözcüklerinden gelmektedir (Williams, 2016, s. 112). Demokrasi, Aristo'nun ifade ettiği gibi Antik Yunan'da bulunan üç yönetim şeklinden biridir. Tek kişinin yönetimde olduğu monarşi ile belli bir zümrenin yönetime hakim olduğu aristokrasiden farklı olarak demokrasi çoğunluğun, yani halkın (demos) yönetimidir. Modern zamanlara kadar geçen yaklaşık 2500 yılı aşkın sürede demokrasi daima tek bir şekilde anlaşılmıştır: "Yoksul çoğunluğun yönetimi”. Yani iyi ile kötüyü ayırt etme yeteneğine sahip olmayan çoğunluğun kendi bildiği gibi yönetmesi olarak anlaşılan demokrasi kavramı, yüzyıllar boyunca "kötü" bir yönetim şekli olarak kabul edilmiştir. Modern dönemde ise kavrama farklı anlamlar yüklenmiştir (Köker, 1994a, s. 3-7). Nitekim, modern tanımlar ortaya çıkmaya başlamıştır. Örneğin Burhan Kuzu'ya göre Amerikalı sosyal bilimciler tarafından en fazla kullanılan tanım Joseph Schumpeter'in tanımıdır: "Politik kararlara varmak için, bireylerin karar alma gücünü, oy almak amacıyla, rekabete dayalı bir mücadele yoluyla elde ettikleri, kurumsal düzenlemedir" (Schumpeter'den akt. Kuzu, 1992, s. 336).

Modern demokrasinin temelde, Rönesans sonrası bir sürece işaret ettiği söylenebilir: Feodalitenin siyasal, kültürel ve ekonomik olarak çözülmesiyle başlayan sürecin bir ürünü olarak öne çıkmaktadır (Köker, 1994a, s. 7). 16. ve 17. yüzyıllarda Batı dünyasında feodalitenin yıkılması ile birlikte merkezileşmeye doğru giden monarşi idareleri (krallıklar) ortaya çıkmaya başlamıştır. Zamanla monarşi hakimiyetinin de sorgulanmaya başlamasılyla birlikte modern anlamda demokrasinin temelleri atılmıştır. Bunun ilk örnekleri 18. yüzyılın sonuna doğru Amerikan Devrimi ve Fransız İhtilali’nde görülmektedir. ABD'de "Bağımsızlık", Fransa'da ise "İnsan ve Yurttaş Hakları” beyannamelerinin ilan edilmesi demokrasi tarihi için önemli gelişmeler olmuştur. Nihayetinde 1791'de kabul edilen Fransız Anayasası ile yurttaşlar kanun önünde eşit kabul edilmişlerdir (Kuzu, 1992, s. 336-337). Eşitlik ilkesi ise modern demokrasi açısından büyük bir önem arz etmektedir. Zira, modern demokrasiyi antik demokrasiden ayıran temel ilkelerden biri bütün vatandaşların eşit olduğu anlayışıdır (Akgün ve Aslan, 2010). 
Modern demokrasi, antik demokrasiden ciddi farklar ile ayrılmaktadır. Örneğin, Antik Yunan dünyasında toplum üç zümreden oluşmaktadır: yurttaşlar, yabancılar ve köleler. Yabancılar ve köleler, yurttaşlarla eşit olmak bir yana, tam anlamıyla insan olarak dahi kabul edilmiyorlardı. Öte yandan yurttaşlık ise, şehir devletinin varlıksal temelini ve sonsuzluğunu ifade eden politeist sembolik sisteme ait olma, yani şehir devletini oluşturan cemaate mensup olma anlamına gelmektedir (Köker, 1994a, s. 5). Dolayısıyla, toplum modelinde bir tür "cemaatçilik" olgusunun hakim olduğu söylenebilir. Böyle bir yapının olduğu yerde, eşitlik anlayışının günümüzden çok farklı olduğu aşikardır. Örneğin, antik demokrasinin zirve yaptığı dönemlerde dahi eşitlik, erkek yurttaşlar arasında geçerliliğe sahip bir olguydu. Öte yandan kadın, köle veya yabancı statüsünde değilse bile, cemaatin üyesi olma özelliğine sahip değildir. Bunun yerine kadın "eve ait" (domestic) olan bir varlık olarak konumlanmıştır (Köker, 1994a, s. 5). Kısacası, Moses I. Finley’in de ifade ettiği gibi "Atina’da yasal ve siyasal haklar, özgürlükler nüfusun belli bir kesimini oluşturan, ayrıcalıklı bir sınıfın yaşayabildiği bir hak olmaktan öteye gidememiştir. Demokrasi, özgürlük, yasalar önünde eşitlik; ontolojik olarak aynı sınıfta bulunan özgür insanlar için geçerli ve anlamlı kavramlardır” (Akt. Akgün ve Aslan, 2010, s. 111).

Modern demokraside eşitlik anlayışı, antik demokrasinin cemaatçilik anlayışından bütünüyle ayrılmaktadır. Cemaatçi anlayışın yerine, toplumun eşit olmayan tabakalara bölünmediği, bireylerin kanun önünde eşit olduğu düşüncesi ön plana çıkmıştır. Bu durumun oluşmasında modern demokrasi düşüncesinde görülen bireysellik ve rasyonalite düşüncesinin de etkin olduğu söylenebilir. Nitekim, toplumsal düşünce yerine bireyi ön plana çıartan, bireyin toplumsal varlığın temeli olduğu, kendi bedeninin (iş yapma, yaratma, emek gücü, vs.) tek sahibi olduğu bir anlayış söz konusu hale gelmiştir. Dolayısıyla bireyler, toplum öncesi ve toplumsal belirlemelerden uzak bir şekilde yaşam, çalışma ve mülkiyet üçlüsüyle dile getirilen doğal haklara sahip olarak kabul edilmişlerdir. Bu bağlamda birey, modern demokrasilerin içinde özne, hür bir yurttaş, yani kendisi için neyin iyi olup olmadığını bilebilme yetisine ve seçimine sahip rasyonel bir varlık olarak konumlanmaktadır. Bireyin hakları ise devletin toplum ve bireyle olan ilişkisi ile ilgilidir. Dolayısıyla modern demokraside devletin gücü ve sınırlarını bireye karşı sınırlandırmak ve bunun anayasa ile güvence altına alınması önemli bir gerekliliği teşkil etmektedir (Köker, 1994a, s. 8-9). Bu bağlamda düşünüldüğünde, bireyin haklarını koruma altına alan insan haklarının uygulanabilmesinin modern demokrasi için önemli olduğu söylenebilir. Zira demokrasinin başarılı olabilmesi için insan haklarına saygı duyulması elzem bir nitelik taşımaktadır (Kuzu, 1992, s. 341). Kaldı ki, Uygun’un (2000) ifadesiyle “...bir devlet düzeninin, bir rejimin değerlendirilmesinde, insan hakları karşısında takınılan tavır, belirleyici bir rol oynar. İnsan haklarına gösterilen saygı, rejimlerin meşruluğunun temel ölçütlerinden biridir” (s. 14).

\section{Demokrasi ve Sinema iliş̧kisi}

Sinema ve demokrasi ilişkisi düşünüldüğünde akla gelen ilk olgu, filmlerin sansüre uğrama tehlikesidir. Kuşkusuz, "Türk sinema tarihi yazımında sık belirtilen hususlardan birisi, sansürün yaygınlığı ve kapsamıdır” (Öztürk, 2013, s. 254). Sansür, ekonomik güçlerden gelebileceği gibi, devlet kurumları tarafından yasalarla düzenlenerek meşrulaştırılan bir mekanizmaya 
da dönüşebilir. Bu tür bir durum ise demokratik sistemi ve ifade özgürlügünü hiç şüphesiz zedelemekte, hatta ortadan kalkmasına neden olmaktadır (Onaran, Abisel, Köker ve Köker, 1994, s. xiii). Zira sanat yapma özgürlüğü, ikinci kuşak insan hakları olarak kabul edilen kültürel haklar kapsamında değerlendirilmektedir. Bunun yanında, sinema yapıtları hem kültürel hakların içinde kabul edildiği gibi hem de düşünce ve kanaatleri açıklama özgürlüklerine ilişkindir. Dolayısıyla sansüre uğrayan bir sinema yapıtı insan haklarına ters düşen bir uygulama olduğu gibi sinematografik özgürlüğe de zarar vermektedir (Kaboğlu, 2000, s. 121, 127-128). Bu nedenle, sinema yapıtı açısından demokrasinin özümsenmesi elzem bir nitelik taşır. Çünkü "[d]emokrasi, farklılıklarla birlikte kaynaşmış, katılımcı ve bu nedenle de rızaya dayalı bir toplumsal yaşam önermektedir. Özgür irade, özgür katılım, özgür ifade, özgür tartışma ortamı bu nedenle büyük önem taşır” (Abisel, 1994, s. 74). Demokrasi dışı bir rejimin olduğu ülkede sinema ideolojik bir propaganda niteliğinden öteye geçemez. ${ }^{2}$

Sansür konusu haricinde demokrasi ve sinema arasında nasıl bir bağlantı kurulacağı sorgulanabilir. Öncelikle, yukarıda da değinildiği gibi medya ve demokrasi bağlamında sinema ve demokrasi ilişkisine dair geniş sayılabilecek bir ulusal ya da uluslararası literatüre rastlamak pek mümkün değildir. Bununla birlikte, sinema ve demokrasi ilişkisini irdeleyen veya bu ilişkiye kısmen değinen geniş kapsamlı olmasa da bazı araştırmalar bulunmaktadır. Örneğin, Douglas Kellner (2010) eski ABD başkanlarından George W. Bush (2001-2009) dönemi Hollywood'unun politik yapısını incelediği çalışmasında film analizinin, çağdaş Amerikan kültürünü ve toplumunu anlamak için önemli bir süreç olduğunu ifade etmekte ve ayrıca; devlet, politika, şirketler, ekonomi, ekonomik-çevresel krizler, terör, savaş, militarizm ve demokrasiye karşı oluşan tehditler gibi tartışma başlıklarına önemli katkılar sağladığını belirtmektedir. Yazar demokrasi ile ilgili iddiasını güçlendirmek için, Bush döneminde Amerikan demokrasinin nasıl zarar gördügünü çeşitli filmlerin anlatıları üzerinden örneklendirir (s. 17, 68-69). ${ }^{3}$ Amerikan demokrasisi ve sinemasına dair dikkat çekici bir diğer çalışma ise Michael Paris’in "Lessons for democracy: American cinema 1942-1945” isimli makalesidir. Paris (1998) makalesinde, İkinci Dünya Savaşı yıllarında Amerikan toplumunun bütünleşmeye ihtiyaç duyduğunu belirtir ve bu bütünleştirme vazifesini üstlenenlerden birinin de Hollywood olduğunu iddia eder. Bu sebeple, dönem içinde (1942-1945) çekilen filmlerde, Amerika’nın farklı etnik gruplarından gelen kişilerin

2 Bu konuya dair güçlü bir örnek İspanya’dan verilebilir. İspanyol diktatör Francisco Franco (1892-1975) İspanya’da iktidarı ele geçirdiğinde ilk iş olarak Ulusal Sinematografi Bölümü’nü kurar. Sinemanın propaganda gücünü iyi bilen Franco, sansür komiteleri kurarak rejimin filmleri denetlemesini sağlar. Bu sansür komiteleri aracılığıyla rejimin ideolojisiyle çatışmayacak, onun talepleri doğrultusunda hareket eden kurmaca bir sinema oluşturulmaya çalışılır. Bununla birlikte Franco yönetiminde birçok İspanyol sinema sanatçısı, özgür bir sinema yapamadıklarından dolayı ülkelerini terk etmek zorunda kalırlar. Francơnun ölümünden sonra (1975) İspanyol sineması sansür baskısından kurtularak normalleşmeye başlamıştır (Yener Gökşenli, 2013, s. 122-124). Sansür konusunun, yukarıda değinildiği gibi, Türk sinemasını da yoğun bir şekilde etkilediği bilinmektedir. Bu konu üzerine literatürde birçok çalışma bulunduğu için, bunları detaylı bir şekilde burada tekrar etme lüzumu görülmemektedir.

3 Örneğin Kellner (2010), Amerikalı yönetmen Michael Moore’un filmlerini analiz eder. Kellner’a göre Moore çeşitli filmlerinde, demokrasinin öneminden ve demokrasinin nasıl zarar gördügünü anlatmaktadır. Bununla birlikte Kellner, bilimkurgu ve fantastik yapımlardan örnek verir. Mesela 2002 yılında George Lucas tarafından yönetilen Star Wars II: Attack of The Clones (Yıldız Savaşları II: Klonların Saldırısı) filminde, Amerikan toplumunun demokrasiye dair endişeleri anlatılmaktadır (s. 132-133,175). 
farklılıklarını bir kenara bırakarak, ortak düşmanlara karşı (Naziler, Japonlar, vs.) mücadele ettikleri anlatılar görülmüştür. Örneğin bu filmlerde, göçmenlere veya Afro-Amerikalılara karşı oluşan tavırların bir kenara bırakılmasına dair anlatılar bulunmaktadır. Paris, bu filmlerin savaş sonrasında tekrar tekrar gösterildiğini ve bu filmleri izleyen Amerikan gençliğinin demokrasi anlayışlarının şekillenmesinde etkisi olabileceğini iddia etmektedir. Bu durumun da Amerikan demokrasisi için olumlu bir süreç olduğunu belirtmektedir (s. 85, 88-90, 94). Bununla birlikte, 1950'li yıllarda Hollywood'da Amerikan ideallerini ve demokrasisini savunan, yücelten; kısacası toplumun demokrasi anlayışını şekillendirmeye veya yönlendirmeye çalışan birçok filmin yapıldı̆̆ da bilinmektedir (Girgus, 1998).

Hollywood bağlamı dışında, demokrasi ve sinema ilişkisinin incelendiği başka çalışmalar da bulunmaktadır. Mesela, Gian Piero Brunetta'nın (1995) "Italian Cinema and the Hard Road Towards Democracy, 1945” isimli makalesinde bu ilişki, İtalyan sineması üzerinden incelenir. Brunetta’ya göre (1995) savaş sonrası İtalyan sinemasında çekilen birçok filmde, İtalyan toplumunun faşizmden demokrasiye geçiş süreci anlatılmaktadır. Brunetta, filmlerdeki karakterlerin faşist rejimde özgürce yaşayamadıklarından ancak demokratik yönetimle birlikte bu özgürlüğe sahip olduklarına dair ifadelerinden örnekler vererek, söz konusu iddiasını güçlendirmektedir (s. 344-347). Bir diğer çalışma ise Akin Adesokan’ın (2009) Nijerya sineması üzerine gerçekleştirdiği "Practising Democracy in Nigerian Films" isimli makaledir. Nijerya'da 1999 yılında, 15 senelik bir askeri yönetimden sonra demokratik seçimler yapılmaya başlanır. Bunun sonucu olarak 2000'li yıllarla birlikte Nijerya sinemasında, Adesokan’n “demokrasi filmleri” olarak adlandırdığı filmler üretilmeye başlanır. Bu bağlamda Adesokan, Akobi Gomina (Yinka Smart-Babalola, 2002) ve Agogo Eewo (Tunde Kelani, 2002) isimli bu iki Nijerya yapımını demokrasi bağlamında inceler. Yazar, filmler üzerinden Nijerya’nın sosyo-politik yapısının nasıl bir dönüşüme uğradığını analiz etmeye çalışır (Adesokan, 2009).

Yukarıda değinilen çalışmalarda araştırmacılar demokrasi olgusunu farklı şekillerde veya bağlamlarda sinema ile ilişkilendirmektedirler. Bununla birlikte, filmlerin demokrasi bağlamında nasıl bir yaklaşımla analiz edileceğine dair bir şablon ortaya konulmamaktadır. Bu noktada, Türkçe literatürde Onaran, Abisel, Köker ve Köker’in (1994) çalışmaları ön plana çıkmaktadır. Bu çalışmanın öneminin filmleri doğrudan demokrasi bağlamında incelemeye çalışması ve buna dair bir yaklaşım geliştirilmesinden kaynaklandığı söylenebilir. Araştırmacılar çalışmalarında 19601980 arasında çekilmiş 47 filmi incelemişlerdir. İnceleme sonucuna göre söz konusu dönemlerde Türk sinemasında çekilen filmlerde daha çok antik demokrasiye dair öğeler bulmuşlardır. Öte yandan, modern demokrasi niteliklerinin onaylandığı filmler azınlıktadır. Bununla birlikte Türk filmlerinde demokratik sorunlara dair eleştirel bir bakış da bulunmamıştır (Köker, 1994b, s. 173).

Söz konusu çalışmada filmlerin nasıl bir yaklaşımla incelendiğine dair çerçeveyi Levent Köker kitaptaki ilk makalede açıklamaktadır. Köker (1994a), modern ve antik demokrasiye dair genel bir çerçeve çizdikten sonra filmlerde söz konusu iki farklı demokrasiye ait olan temaların nasıl işlendiğinin ortaya çlkarılmasını önerir. Bunun yanında eleştirel bir yorumlamaya ihtiyaç duyulacağını belirtir ve bunu gerçekleştirmek için de işlenen temalara denk düşen üç farklı düzey arasında bir ayrım yapmak gerektiğini ifade eder. Bu düzeyler dünya görüşü, kişilik ve kişiler 
arası ilişkiler, kamusal otorite (devlet) ve siyasal ilişkiler başlıkları altında formüle edilir. Dünya görüşü düzeyinde filmin tasarladığı dünyayı (onaylıyor mu yoksa eleştiriyor mu?) nasıl gördüğü irdelenmektedir. Bu noktadaki ayrım kesinlik taşımamaktadır. Çünkü filmler, bazı durumlarda eleştirel bir perspektif sunabileceği gibi, bazı durumları da onaylayabilirler. Ancak dikkat edilmesi gereken husus eleştiri ve onaylama durumlarının nasıl bir dünya görüşüne dayandığıdır. $\mathrm{Bu}$ şekilde ne tür bir demokrasi anlayışına zemin oluşturduğu da incelenmiş olacaktır (s. 9-14). Mesela Abisel (1994), "Nasıl Yaşıyor, Nasıl Düşlüyoruz?” isimli çalışmasında incelenen filmleri üç başlık altında toplamaktadır: "temsil ettiği dünyayı beğenenler", "temsil ettiği dünyadaki çelişkilerin yumuşatılmasını isteyenler” ve "temsil ettiği dünyayı beğenmeyenler” (s. 104-109). Abisel'in bu düzeye dair kategorileştirmesi, benzer şekilde bizim çalışmamızda da kullanılabilir. İkinci düzey olarak filmlerde kişiliklerin ve kişilerarası ilişkilerin nasıl işlendiğine dikkat edilmesi üzerinedir. Yani filmlerdeki karakterlerin "otoriter" veya "demokratik" nitelikleri incelenir. İki kişilik tipinin demokratik olup olmadığını belirlemek için ise; hoşgörü, çoğulculuk, katılımcılık, eleştirellik gibi niteliklere bakılır. Bunların yanında filmlerde yer alan kadın temsilleri de ayrı bir şekilde irdelenmelidir. Mesela kadın karakterlerin özne olup olmadığının (kendi kaderini kendi tayin eden) sorgulanması gereklidir. Filmlerde incelenmesi gereken üçüncü düzey ise inşa edilen anlatı dünyasında siyasal ilişkilerin ve kamusal otoritenin nasıl bir şekilde konumlandığ 1 ile ilgilidir. Kamusal otoriteye nasıl bakıldığı, siyasal ilişkiler içerisinde olan karakterlerin özellikleri, demokratik sürecin temel kurumlarının (siyasal partiler, seçimler, parlamento, vs.) ve ideolojilerin temsil edilişi gibi benzeri olgular sorgulanmaktadır (Köker, 1994a, s. 9-14).

$\mathrm{Bu}$ genel çerçeveden sonra araştırmacılar kurulan çerçeveye sadık kalarak farklı şekillerde filmleri incelemişlerdir. Bu çalışmada, ilk etapta filmlerin kısa özetleri verilecektir. Ardından filmler, yukarıda zikredildiği gibi üç düzey (alt başlık) altında incelemeye tabi tutulacaktır. Öncelikle filmlerin kişileri, ardından kamusal otorite ve siyasal ilişkiler, son olarak ise filmin dünya görüşü incelenecektir.

\section{Çoğunluk}

Çoğunlukfilmiüst-orta sınıfıniçindeyeralan Mertkan’ınözneolma sürecineodaklanmaktadır. Mertkan, babasının otoritesi altında ezilmiş, hayatta herhangi bir amacı olmayan, insanlarla iletişimi (özellikle karşı cinsle) problemli olan bir bireydir. Mertkan babasının yanında çalışır ve onun dediklerini yerine getirmeye çalışan biri olarak görülür. Filmde Mertkan’n babasından ve çevresinden gelen baskılar altında ezilmesi, kimliğini tam manasıyla oluşturamama sıkıntısını izleriz. Ancak filmin sonuna doğru kendi sınıfına uygun bir birey olarak babasına benzemeye başladığı görülür.

\section{Kişiler ve Kişiler Arası İlişkiler}

Film temelde arzu etmediği halde babasına benzemeye başlayan Mertkan’n hikayesini anlatmaktadır. Giriş sahnesinde Mertkan’ın çocukluğunu görürüz. Mertkan, babası Kemal ile birlikte ormanda yürüyüş yapmaktadır. Sahnede babası önde hızlı bir şekilde yürürken, Mertkan 
ise arkasından yetişmeye çalışmaktadır. Bu sahne ile aslında Mertkan’ın babasına benzeme sürecindeki süreklilik filmin hemen başında ima edilir (Thwaites, 2012, s. 167). Filmin bir sonraki sahnesinde Mertkan’ın evin temizliğini yapan Şükriye’ye fiziksel olarak şiddet uyguladığı görülür. Bu sahnede aslında babasına özendiği yorumu yapılabilir. Zira Kemal de Şükriye’nin o gün evde olmasından rahatsızdır. Kemal'in ailesi, özellikle de Mertkan'ın üzerinde mutlak bir iktidarı bulunmaktadır. Mesela tam vaktinde yemek masasında herkesin bulunmasını ister, oğlunu istediği yerlere zorla götürür (örneğin sauna). Kemal, gerektiğinde Mertkan’a şiddet uygulamaktan, küfür etmekten hatta onu çeşitli şekillerde cezalandırmaktan da geri durmaz. Filmin başlarında Mertkan, yemek masasına geç geldiği ve işten erken çıktığı için Kemal, ertesi gün Gebze'deki şantiyeye ihtiyaç olmadığı halde kereste götürmesini emreder. Mertkan bu duruma itiraz etse de babasının emrine uyar. Dolayısıyla Kemal mutlak özne (iktidar) iken, ailesi ise mutlak nesne konumunda yer alır (Deniz ve Akmeşe, 2015, s. 89). Kemal oğlu üzerindeki iktidarını mutlak bir vaziyette tutmak için, Mertkan’ı her daim gözetim altında tutar. Örneğin onun kiminle görüştügüne, kiminle sevgili olduğuna dahi karışır. Mertkan’’n Gül ile olan ilişkisine ilk başta karşı çıkmaz. Ancak Gül'ün Vanlı olduğunu öğrendiğinde hiçbir gerekçe göstermeden bir an önce Mertkan’n Gül'ü terk etmesini emreder. Ancak Mertkan bunu ilk etapta yapamaz. Bunun üzerine babası sürekli olarak Gül’ü terk edip etmediğini sorar. Sonunda terk etmediğini öğrendiğinde ise Mertkan ile konuşur ve "takıldığı kişilere dikkat etmesi gerektiğini, Gül gibi kişilerin vatanı bölme niyetinde olduğunu” ifade eder. Bu ifadeleri ile Kemal, aslında Gül'ün Kürt olduğunu ima eder ve bir tür ötekileştirmeye başvurur. Şayet bu noktada Edward Said’den yararlanırsak, Kemal'in ötekilik üzerinden iktidarını nasıl pekiştirdiğini anlayabiliriz. Said'e göre "Öteki, kavramlara ilişkin bir kültürel projeksiyon biçimi olarak görülebilir. Bu projeksiyon Öteki’nin tabi unsur olduğu bir iktidar ilişkisi yoluyla kültürel öznelerin kimliklerini oluşturur” (Said'ten akt. Edgar ve Sedgwick, 2007, s. 251-252). Dolayısıyla Kemal bu sahnede dış-kümelere (farklı etnik, sınıf, vs.) saldırganlık içinde olan bir birey olduğunu da göstermiş olur.

Kemal'in doğrudan gözetleme ve bilgi üzerinden iktidarını kurduğu söylenebilir. Zira doğrudan gözetlemek veya kişinin hakkında malumat sahibi olmak bir tür iktidar ilişkisi yaratır (Lyon, 2013, s. 125-126). Kemal iktidarının sarsılma durumuna karşın ceza yöntemine başvurur. Örneğin ihtiyaç olmadığı halde Mertkan’ı Gebze'deki şantiyeye gönderir. Filmin sonlarına doğru yine ceza maksadıyla askere gitmesini, askere gidene kadar ise Gebze'deki şantiyenin başında olmasını emreder. Foucault'un (2015) panopticon modeliyle ifade ettiği gibi bireyleri terbiye etme arzusu ile onların üzerinde çeşitli cezaları denemek; cezaları bireyin karakterine uygun olacak şekilde uygulamak, bir tür iktidar (tahakküm kuran ve kurulan) ilişkisi yaratmaktadır (s. 299-301). Nitekim Mertkan filmin sonlarına doğru artık gözetlenmeyi içselleştiren bir konuma doğru evrilir. Zira “[g]özetleyen bir bakış ve bakışın ağırlığını üzerinde hisseden herkes, bakışı öyle içselleştirir ki, sonunda kendini gözleme noktasına varır; böylece herkes kendi üzerinde ve kendine karşı bu gözetlemeyi işletecektir” (Foucault, 2012, s. 95). Nitekim Mertkan gözetlenmeyi içselleştirdiği gibi babasının memnun kalacağı bir bireye de dönüşmeye başlar. Örneğin Gebze'deki şantiyede gerekli olmadığı halde bir işçiyi azarlayarak, tahakküm kurmaya çalışır. Bununla birlikte babasından bir silah talep ederek, yeni kuracağı iktidarını "dış mihraklara” karşı 
korumaya çalışır. Filmin sonunda eve gelen Mertkan’a babası ilk kez güler yüzünü gösterir, hatta ona sarilır.

Kemal'in saygı duyduğu kişiler ise kendisiyle ancak "aynı cemaati” paylaşan, kısacası iktidar (erk) sahibi insanlardan oluşmaktadır. Örneğin büyük oğlunun üzerinde tahakküm kurmaya dair bir emareye filmde rastlayamayı. Çünkü büyük oğlu evlenerek, kendi ailesi üzerinde iktidarını kurmuştur. Hatta büyük oğul, Mertkan’a “Sen de evlen kurtul!” diyerek iktidar sahibi olması gerektiğini salık verir. Diğer taraftan Kemal, kendi gibi iktidar sahibi arkadaşlarına da saygı duyar. Mesela sauna sahnesinde diğer arkadaşları üzerinde doğal olarak iktidar kurmaya çalışmaz. Onlara karşı herhangi bir saygısızlık yapmaz. Aksine bu sahnede iktidar sahibi olduğunu, Mertkan’ı saunanın üst kısmına göndererek gösterir. Mertkan’’n itirazı üzerine Kemal, "Ben mi çıkacağım oraya?" diyerek emirlerinin sorgulanmasını kabul etmez. Bununla birlikte Kemal'in arkadaşlarının da iktidar sahibi oluşu Necmi karakteri üzerinden inşa edilir. Mertkan’ın polis raporunu, rüşvet teklif etmesine rağmen, değiştirtememesi üzerine Kemal, Necmi’den raporu değiştirtmesini rica eder. Nitekim Necmi, tam olarak anlaşılamayan bazı bağlantılarını kullanarak polis raporunun değiştirilmesini sağlar.

Kemal'in anne karakteri üzerinde de tahakkümü bulunmaktadır. Mesela Mertkan babası ile ters düştügüunde annesi, kendisini babası ile karşı karşıya getirmemesini söyler. Anne karakteri hiçbir zaman özne haline gelemez. Her zaman için Kemal’e bağımlılı̆̆ bulunmaktadır. Kaldı ki anne karakteri film boyunca çoğunlukla evin içinde konumlanır. Keza filmdeki diğer kadınların da tam bir özne oldukları söylenemez. Örneğin temizlikçi Şükriye eşinden dayak yemektedir ve anlaşıldığı kadarıyla kendi evinde çalışan tek bireydir. Filmin ilerleyen kısımlarında Şükriye’nin çocuğuyla birlikte öldüğünü öğreniriz. Dolayısıyla Şükriye’nin de iktidar sahibi ‘düzgün’ bir eşten yoksun olduğu açıktır. Öte yandan Gül karakteri Van’dan okumak ve çalışmak için İstanbul'a gelmiştir. Ailesinden ayrı yaşamaktadır. Bu durum ilk etapta Gül'ü kendi kaderini tayin eden bir birey gibi gösterir. Ne var ki ilerleyen kısımlarda Gül, "en büyük hayalinin yakışıklı bir erkek bulup evlenmek” olduğunu söyler. Gül'ün bu ifadesi onun bir erkeğe muhtaç olduğunu imlemektedir. Kaldı ki, ilerleyen sahnelerde Mertkan, belli bir süre Gül'den ayrı kalmak istediğini söyler. Bu sahnede Gül adeta Mertkan’ın kendisini bırakmaması için yalvarır. Dolayısıyla Gül'ün de tam anlamıyla bir özne olduğunu söylemek mümkün değildir. Nitekim hem Gül'ün hem de Şükriye’nin durumu “...iktidar sahibi bir kocaya sahip olmayan kadının tek başına yaşama şansının olmadığı yönündeki erkek egemen toplumsal yargının ifade edilmesi olarak yorumlanabilir” (Deniz ve Akmeşe, 2015, s. 94).

Filmin karakterlere dair çizdiği zikredilen özellikler göz önünde bulundurulursa, öncellikle Kemal'in demokratik bir kişi olarak nitelemenin pek mümkün olmadı̆̆ 1 ifade edilebilir. Nihayetinde demokratik bir toplum arzusu duyulan bir ülkede demokratik kişilerin ortaya çıkması elzem bir nitelik taşımaktadır (Kuzu, 1992, s. 365). Kemal, mutlak iktidarını kimseyle paylaşmayan (ve sorgulatmayan), çoğulculuğa karşı, tartışma kültüründen nasibini almamış, dış-kümelere karşı saldırganlık içinde olan, ataerkil düzenin savunucusu, katı kurallara bağlı, eleştirellikten uzak, iktidar ilişkilerine önem veren bir insan modeli sunmaktadır. Bu özelliklere haiz olan bir bireyin ise modern demokrasiden nasibini aldığını söylemek mümkün değildir 
(Onaran, 1994, s. 15-25). Buna rağmen Kemal'in antik demokrasinin "cemaatçi yurttaş" anlayışına yaklaşan yanları olduğunu belirtmek de mümkündür. Zira bilindiği üzere antik demokraside, eşit yurttaşlar sadece erkeklerden oluşur. Bu anlamda Kemal ve onunla aynı iktidar gücüne sahip erkeklerin (örneğin Kemal'in büyük oğlu ve arkadaşı Necmi) eşit yurttaşlar olarak konumlandığını söylemek mümkündür. Mertkan ise şayet babası gibi bir insana dönüşürse eşit yurttaş statüsüne sahip olacaktır. Öte yandan filmde yer alan kadınlar ise gerek özne olamamaları gerekse eve ait olarak (domestic) konumlanmaları bakımından, antik demokrasinin kadınlar için ön gördüğü modelin içinde yer almaktadırlar. Kısacası filmde yer alan kişilerin modern anlamda demokratik kişilere ve ilişkilere sahip oldukları söylenemez. Ancak karakterlerin antik demokrasinin savunduğu projeksiyona büyük anlamda uyduğu yorumu yapılabilir.

\section{Kamusal Otorite (Devlet) ve Siyasal İlişkiler}

Filmin, tahakküm kurma anlamında en güçlü karakterini oluşturan Kemal'in kapitalist ve faşist bir ideolojide olduğunu söylemek mümkündür. Gerek kendinden aşağı sınıfta olanlara küçümsemesi (Mertkan’nn alkollü bir şekilde araç kullanırken aracına çarptığı taksi şoförünü dilencilikle suçlaması) gerekse Türklerden başka etnisiteyi ötekileştirmesi (Güle karşı olan tavrı) bu niteliklere işaret etmektedir. Bunlara rağmen hem Kemal'in hem de diğer karakterlerin herhangi bir siyasi kuruma bağlı olduklarına dair bir emare filmin içinde yer almamaktadır. Dolayısıyla filmdeki siyasi ilişkiler üzerine yorum getirmek zordur. Ne var ki, kapitalist ve faşist ideolojilerin demokrasinin önündeki engel olarak filmde sunulduğu da aşikardır. Bu durumu karakterlerin kamusal otoriteye ait bazı organlarla olan ilişkilerinden anlamak mümkündür. Mesela Mertkan’ın alkollü araç kullanarak kaza yapması ilk kertede polis raporuna yansır. Ancak Kemal, Mertkan'dan polis ile konuşarak bu durumu düzeltmesini ister. Mertkan polise rüşvet teklif etmesine rağmen polis raporu değiştirmeyi kabul etmez. Bu kısımda polisin hukuk devletine (ve demokrasiye) uygun bir şekilde kanunsuzluk yapmadığı görülür. Fakat ilerleyen sahnelerde Kemal, bu durumu düzeltmesi için Necmiden ricada bulunur. Sonrasinda Necmi kendi bağlantılarını kullanarak durumu düzeltir ve Mertkan düzeltilmiş raporu doğrudan Necmi’nin elinden alır. Mertkan, polise karşı başarısız olmuştur. Çünkü babası veya Necmi gibi nüfuz sahibi (özne) değildir. Ancak Necmi bu durumu kolaylıkla halleder. Hem Kemal'in hem de Necmi'nin faşist ve kapitalist ideolojilerin içinde temsil edilmesi ve polis raporunu değiştirecek kadar iktidar ilişkilerine sahip olmaları, bizatihi bu ideolojileri demokrasi anlamında töhmet altında birakmaktadır.

\section{Filmin Dünya Görüşü}

Filmin tasarladığı dünya görüşünün, kişiler ve kişiler arası ilişkiler ile kamusal otoritenin irdelendiği bölümlerde de görüleceği üzere, tasdik edilmediği belirtilmelidir. Bu anlamda film, kurduğu kurmaca dünyaya karşı eleştirel bir tutum takınarak, toplumun demokratik normlar üzerinden yükselmediğinin altını çizmektedir. Gerek erkek karakterlerin iktidar ilişkilerine önem veren, çoğulculuğa karşı, ötekileştiren, ataerkil düzeni savunan, vb. özelliklere sahip olması, gerekse kadınların özne olamadıkları gibi eve ait olarak da resmedilmesi ifade edilen bu 
duruma dair işaretlerdir. Üstelik filmde, hem kamu otoritesine dair organlar hem de karakterlerin ideolojileri eleştirel bir perspektifle çizilmektedir. Kaldı ki filmin yönetmeni ve senaristi Seren Yüce de filmin eleştirel tutumunu onaylamaktadır. Örneğin, verdiği bir söyleşide yönetmen filmde işlediği meselelerin ötekileştirme ve ayrımcılıkla ilgili olduğunu ifade eder. Bunun yanında Yüce, özellikle "ezenlerin" yani toplumda baskın, çoğunluk olan kesimin hikayesini anlatmak istediğini vurgular (Aytaç ve Öperli, 2010, s. 34-35). Abisel’in (1994, s. 109) yukarıda açıklanan kategorilerinden yararlanacak olursak, filmin kesinlikle "temsil ettiği dünyayı beğenmediği" ifade edilebilir. Filmin bu bağlamda temsil ettiği dünyanın değişmesini arzuladığı yorumu yapılabilir.

Kısacası, üç farklı düzeyde incelendiği üzere Çoğunluk filminde inşa edilen kişisel, toplumsal ve kamusal tasavvurların modern anlamda demokratik bir düzene işaret etmediği görülmektedir. Bunun yanında, filmin dünya görüşü tarafından onaylanmayıp eleştirilse de, anlatıda antik demokrasiye dair bazı emarelerin yer aldığ 1 söylenebilir.

\section{Tepenin Ardı}

Faik, Orman İşletmesỉnden emekli olduktan sonra babasından kalma araziyi işlemektedir. Arazideki işlere yardım etmek için yanında Yörük bir aile çalışmaktadır. Bir yaz günü oğlu Nusret ile torunları Zafer ve Caner Faik'in yanına tatil için gelirler. Bu arada Faik karşı tepenin arkasında bulunan Yörüklerle, sürülerini Faik'in arazisinde otlattıkları için amansız bir kavgaya tutuşmuştur. Yörüklere büyük bir öfke duyan Faik, onları cezalandırmak için sürüden bir keçiyi de alıkoymuştur. Hem ailenin kendi içinde yaşadığı problemler hem de yanlarında çalışan Yörük aileyle yaşanan sorunlar, durumu daha da karmaşıklaştırır. Yaşanan problemlerin sorumlusu olarak tepenin ardında yaşayan Yörükler görülür. Faik’in liderliğinde Yörüklere karşı savaş açılır.

\section{Kişiler ve Kişiler Arası İlişkiler}

Filmin hemen başında Faik'in bazı sesler duyması üzerine hızla yataktan kalktığını ve tüfeğiyle dişarıya doğru koştuğunu görürüz. Esasında, ilerleyen sahnelerde anlaşılacağı üzere Faik, Yörüklerin arazisini ihlal etmelerini bahane ederek tüfeğiyle birlikte koşmuştur. Dolayısıyla daha filmin başlarında Faik'in şiddete meyilli bir birey olduğu imlenir. Nitekim Faik, filmin ilerleyen sahnelerinde de görüleceği üzere öfkesiyle hareket eden, şiddete meyilli, hoşgörüden uzak, diğer bireyler üzerinde tahakküm kuran bir karakterdir. Mesela, torunu Caner’e tüfekle ateş etmeyi öğretir ve hedefi vurduğu için onu takdir eder. Arazisini ihlal ettikleri bahanesiyle Yörüklerin çobanını döver ve sürüsünden bir keçiyi alıkoyar. Buna karşı çıkan diğer bireyleri (örneğin Nusret’i) öfkesiyle susturur. Yaptığı bu davranışı ise sonuna kadar haklı görür, Yörüklerin "laftan" anlamadığını, ancak sert önlemler alınırsa yola geleceklerini şu sözlerle ifade eder: "Ben bunları bilmez miyim? Bunların gözünü korkutmazsan hiçbir şey yaptıramazsın.” Faik’in bu ifadesinin öncesinde Nusret, babasının kanuni mecralara neden başvurmadığını sorgular. Faik ise birçok defa jandarmaya, kaymakama şikayet ettiğini ancak "Faik Bey bizim bunlara sözümüz geçmiyor” cevabıyla karşılaştığını söyler. Faik aslında bu ifadesiyle gerçekleştirdiği şiddeti ve hukuksuzluğu meşrulaştırmaya çalışmaktadır. Nitekim filmin sonuna kadar Faik, Yörüklere 
karşı birkaç defa şiddet uygulamaya çalışır ve kanuni mecralara başvurmayı reddeder. Örneğin Meryem, yaşanan olaylardan dolayı iki kez jandarmaya haber verilmesi gerektiğini ifade eder. Fakat Faik bu tavsiyelere kulak asmaz. Faik'in mevzubahis tavrı onun istediklerini şiddet yoluyla halletmeye çalışan, hukuk tanımayan bir karakter olduğunu göstermektedir.

Faik'in Yörüklere bu kadar öfke duymasının en önemli sebebi ise, Yörüklerin onun iktidar alanının dışında ve iktidarını tehdit eden bir konumda bulunmalarıdır. Zira "Yörükler Faik’in söyleminde toplumsal alanın belirleyicisi olan ve toplumsalın sınırlarını çizen kanunların dışında bir tehlike olarak kurulur" (Gündoğdu, 2014, s. 36). Dolayısıyla Faik dış-kümelere saldırgan bir tavır içindedir.

Faik kesin bir şekilde, iktidar alanını tehdit edecek bir ortağı kabul etmez. Bundan dolayı film boyunca Faik'in emirleri çok fazla sorgulan(a)maz. Nitekim filmin sonunda Faik'in adını koyduğu ortak düşman üzerinde bütün erkekler birleşirler (Gön, 2014, s. 66). Sadece Nusret, Faik'in iktidarı karşısında kısmi bir istisnai durum sergilemektedir. Nusret, babasının Yörüklerle çatışmasına karşıdır ve bunu yüksek sesle dile getirir. Ancak Faik, oğlunu dinlemez ve onu susturur. Bu örnek haricinde Faik'in iktidarı sorgulanamazdır. İktidar alanını korumak içinse çeşitli yollara başvurur. Mesela arazisinin sınırlarını sürekli dürbünüyle gözler. Gerektiğinde tüfeğini kullanmaktan çekinmez. Dürbün ve tüfek, gözetimin ve şiddetin sağladığı iktidar gücünü adeta somutlaştıran nesnelerdir. Kendi ailesi üzerinde kurduğu tahakkümün yanı sıra, Mehmet ve ailesi üzerinde de tahakküm kurmaktadır. Örneğin Faik’e olan borcunu ödeyemeyen Mehmet'e teklifi sürüsünde yer alan keçileri ona devreder. Kurulan tahakkümün emek üzerinden vücut bulan bir yanı olduğu gibi bedensel bir yanı da bulunmaktadır. Örneğin Faik, Meryem’e sarkıntılık etmekte herhangi bir sakınca görmez. Çünkü Gündoğdu’nun da (2014) belirttiği gibi oradaki her şey Faik'in "tapulu malıdır", yani iktidar alanının içindedir (s. 38). Ne var ki Faik kendi ifadesiyle genç olmadığı için Meryem’e karşı olan arzularını tam anlamıyla eyleme geçiremez. Ancak "daha genç" olan oğlu Nusret, Meryem’e cinsel saldırıda bulunur. Dolayısıyla Faik ve oğlu Nusret'in, Mehmet ve ailesi üzerinde mutlak bir iktidarları, hatta mülkiyetleri bulunmaktadır. Halbuki modern demokrasinin temel öğelerinden birisi bireyin yaşam-çalışmamülkiyet üçlüsüyle ifade edilen doğal haklara sahip olmasıdır (Köker, 1994a, s. 8). Ancak Mehmet ve ailesinin bu haklardan özgür bir şekilde yararlandıkları söylenemez.

Tahakküm sınırlarının böylesine ayrıldığı bir yapıda erkekler ile kadınların dünyası da birbirinden keskin sınırlarla ayrılmaktadır. Örneğin Meryem evle, bilhassa mutfak işleriyle özdeşleşmiştir. Diğer taraftan erkekler ise, keçi gütme ve kesme, nöbet tutma, silah kullanma, araziyi kontrol etme fiilleriyle birlikte açık alanların tamamına hakimdirler (Gön, 2014, s. 64). Meryem böylesine ataerkil bir düzlemde salt bir şekilde nesne olarak konumlanmaktadır. Meryem, evle özdeşleşmesinin ötesinde uğradığı cinsel saldırıya dahi tam manası ile itiraz edemez, "kaderini” kabullenir. Bunlara rağmen Meryem’in hukuk tanır bir yanı olduğunu da belirtmek gerekir. Meryem, erkeklerin aksine, olayların daha da karışmasını engellemeye çalışır ve jandarmaya haber verilmesini salık verir. Ancak başta Faik olmak üzere hiçbir erkek onu dinlemez. 
Karakterler ve aralarındaki ilişkiler göz önünde bulundurulduğunda, filmde modern demokrasiyle özdeşleşebilecek kişilikler yer almamaktadır. Faik çoğulculuğa karşı, dış-kümelere saldırganlık içinde, ataerkil düzenin savunucusu, iktidarını hiç kimse ile paylaşmayan, şiddete başvurmaktan çekinmeyen bir karakterdir. Oğlu Nusret ise, Faik kadar muktedir olmamasına rağmen babasından sonra en yetkili kişi konumunda yer almaktadır. Bu anlamda Faik ve Nusret'in antik demokrasilerde yer alan eşit yurttaşlar olarak konumlandıkları söylenebilir. Keza diğer karakterlerin de antik demokrasinin öngördüğü kişiliklere uyduğu görülmektedir. Meryem evle özdeşleşen, özne olamayan bir konumda yer alır. Mehmet ise, Antik Yunan'da cemaatin içinde yer almayan köle sınıfında olarak kabul edilebilir. Mehmet, Faik'in bazı davranışlarından, hatta eşi Meryem ile yalnız konuşmasından dahi rahatsız olur ancak itiraz edemez. Sadece Faik'in arazisine zarar vermekle yetinir. Dolayısıyla Mehmet, iktidar sahibini karşı koyamayan köle konumuna yerleşmiş olur. ${ }^{4}$

\section{Kamusal Otorite (Devlet) ve Siyasal İlişkiler}

Başta Faik olmak üzere hiçbir karakterin herhangi bir siyasi kuruma, partiye bağlı olduğuna dair bir belirti filmde yer almamaktadır. Ancak Faik'in toprak ağası olarak konumlandığı ve doğal olarak kapitalist bir ideolojiye sahip olduğu aşikardır. Bu durumu Meryem'in Faike "Faik Ağa" olarak seslenmesinden de anlamak mümkündür. Dolayısıyla "ağa" statüsünde bulunan Faik'in, bireylerin modern demokrasi içinde elzem bir nitelik taşıyan yaşam-çalışma-mülkiyet üçlüsünün özgürce yaşanması bakımından bir engel teşkil ettiği aşikardır. Faik, görünürde kapitalizm haricinde bir ideoloji taşımamasına rağmen, Yörüklere olan tavrından dolayı devletin resmi ideolojisini temsil ettiği yorumu yapılabilir. Yörük, konargöçer Türkleri adlandırmak için ortaya çıkmış bir ifadedir. Yörükler tarihleri boyunca şehirden uzakta, göçebe bir hayat tarzı benimsemişlerdir. Gerek Selçuklular gerekse Osmanlılar Yörüklere karşı iskan politikası uygulamaya çalışarak onları yerleşik hayata geçirmeye çalışmışsa da Yörüklerin bu tür girişimlere sıcak bakmadığı ve direndiği bilinmektedir (Doğan, 2012, s. 117, 124). Kısacası, Yörüklerin devlet otoritesi ile her daim problem içeren bir yanları olduğu aşikardır. Faik de devletin Yörüklerle olan problemli yanını anlatan somut bir örnek olarak filmde yer alır. Bu sebeple Faik, Yörükleri bir tür öteki olarak inşa eder. Onlara sert bir şekilde davranarak, itaat etmelerini sağlamaya çalışması boşuna değildir. Breton’a (2010) göre acı vermek ve bunun aracılığıyla itaat sağlamaya çalışmak bir güç gösterisinden başka bir şey değildir. İktidarın gizli, gölgede kalmış bir yüzüdür ve öteki üzerinde bir egemenlik kurma biçimidir. Ötekinin kimlik duygusunu parçalamak, yıkmak ve adeta eşya konumuna düşürmek temel amaçtır (s. 186-190). Filmin çeşitli okumalarında da ötekilik mevzusu ön plana çıkmaktadır (Büte, 2013). Kaldı ki, yönetmen Emin Alper de filmin ötekilik üzerinden Türkiye siyasetine atıf yaptığını "Türkiye siyaseti ötekiler inşa etmekten, suçu başkasına atmaktan kendi problemini görmezden gelme hastalığından yıllardır mustarip”

4 Yetişkinler antik demokrasi modeli içinde konumlanırken, çocukların konumunun ise muğlak kaldığı yorumu yapılabilir. Zafer travmatik bir geçmişe sahip olduğu ve zihni melekelerinde problemler yaşayan biri olduğu için, topluluğun dışında yer almaktadır. Caner ise tam manası ile özne olamamıştır ancak büyüklerini (dedesi ve babası) takip etmektedir. Diğer taraftan Sülü ise kendini topluluğun dışına atarak, yabanıl bir hayat benimsemiştir. Kısacası filmde yer alan çocukları antik veya modern demokratik kişiliklerin içine yerleştirmek zor gözükmektedir. 
sözleriyle ifade etmektedir (Aytaç ve Göl, 2012, s. 31). Dolayısıyla filmde söz konusu siyasetin altı, Faik üzerinden çizilerek, bu siyasetin demokrasiyi baltaladığg görüşü vurgulanır.

\section{Filmin Dünya Görüşü}

Filmin inşa ettiği kurmaca evrene karşı eleştirel bir tutum takındığı, yukarıda ayrıntılı bir şekilde tespit edildiği üzere, aşikardır. Gerek Faik’in sahip olduğu nitelikler, gerekse filmin tek kadın karakteri olarak Meryem’in konumu, söz konusu eleştirel tutuma dair en büyük örneklerdir. Kısacası, filmin temsil ettiği dünyayı beğenmediği açık bir olgudur. Filmin eleştirel tutumu, yönetmenin verdiği söyleşilerde de görülmektedir. Emin Alper verdiği bir söyleşide kadının (Meryem) durumundaki ezilmişlikten ve kaderini kabul ettiğinden dem vurur. Bunun yanında Alper, Faik'in devleti temsil eden, çocukların ise hiçbir zaman kendini devlete beğendirememiş vatandaşları temsil eden bir yanları olduğunu da ifade eder (Kılıç, 2013, s. 4-5).

Üç farklı düzeyde değinildiği üzere Tepenin Ardı filminde inşa edilen kişisel ve toplumsal tasarımlar modern anlamda demokratik bir düzeni temsil etmemektedir. Ancak filmin eleştirel tutumu gereği, onaylanmasa da antik demokrasiye dair bazı emarelere rastlanabilir.

\section{Sonuç}

Yakın dönem Türk sinemasında iki farklı filmi incelediğimiz bu çalışmada, inşa edilen kurmaca evrenlerin demokratik bir topluma, düzene işaret etmediği görülmüştür. Filmlerin içeriğinde demokratik temsil sorununa eleştiri getirilmiştir. Her iki filmde de yer alan karakterler ve bunun üzerinden şekillenen toplumsal yapının, modern demokrasinin ön gördüğü niteliklerden uzak olduğu açıktır. Zira modern demokrasi, antik demokrasinin aksine kadın-erkek bütün bireyleri eşit yurttaşlar olarak nitelemektedir. Örneğin kadınlar antik demokraside yurttaş olarak görülmez ve eve ait olarak konumlanırlar. Modern demokrasi ise bu anlayışı reddeder. Dolayısıyla filmlerde kurulan yapının antik demokrasinin niteliklerine sahip olduğu söylenebilir. Dolayısıyla her iki filmde de inşa edilen kurmaca dünyada, modern demokrasi anlamında bir olgunun bulunmadığını ancak bir tür demokrasi adlandırması yapılacaksa, bu demokrasinin Antik Yunan demokrasisi olabileceği vurgulanmaktadır. Özellikle erkek karakterlerin eşit yurttaşlar (cemaatçi) olarak konumlanmaları, kadınların ise erkek tahakkümü ve bağımlılığı altında yaşayan nesneler olmaları, antik demokrasiye dair işaretlerdir.

Bu tür bir sonuç, Onaran vd. (1994) çalışmalarında ulaştıkları sonuçtan çok da farklı değildir. Kısacası, yukarıda değinilen araştırmacıların incelediği filmlerde (1960-1980) tasarlanan demokratik yapının, uzun yıllar geçmesine rağmen, yakın dönemde çekilen filmler ile arasında büyük bir fark arz etmediği görülmektedir. Ancak burada tespit edilen farklı bir olgu, her iki filmin de temsil ettikleri dünyayı beğenmedikleri ve eleştirel bir tutum içerisinde olmalarıdır. $\mathrm{Bu}$ durumu yönetmenlerin söyleşilerinden çıarmak mümkün olduğu gibi, filmlerde tespit edilen ve demokrasinin önünde engel olarak konumlanan olgulardan da anlamak mümkündür. Örneğin, her iki filmde de baba karakterleri mutlak iktidarı temsil etmektedirler. İktidarlarının ise son derece otoriter, hukuksuz, çoğunlukçu olmayan, hoşgörüden uzak, dış-kümelere saldırganlık 
içinde olan, ötekileştiren, ataerkil, şiddete başvurmaktan çekinmeyen, eleştirellikten uzak ve iktidar ilişkilerine önem veren bir konumdan yükseldiği görülmektedir. Diğer taraftan her iki filmde de görüleceği üzere kapitalist ideolojinin getirdiği sınıfsal iktidar ilişkilerinin demokratik bir toplumun önünde engel teşkil ettiği filmlerde altı çizilerek vurgulanmaktadır. Bunun yanında Çoğunluk filminde faşist ideolojinin de demokrasiyi baltaladığı düşüncesi görülmektedir.

İktidarın baba karakterleri üzerinden somutlaştırılması ise filmlerde dikkat çekici bir diğer noktadır. Bu anlamda baba karakterlerinin (devlet-baba) devlet ile özdeşleştirildiği yorumu yapılabilir. Baba temsillerinin iktidarlarını korumak için gözetim yoluna gitmeleri ise, gözetim toplumu olgusunun filmlerde vücut bulmasıdır. Dolayısıyla her iki filmde tasarlanan yapının, toplumu mikro ölçekte temsil eden örnekler olduğu söylenebilir. 


\section{Kaynakça}

Abisel, N. (1994). Nasıl yaşıyor nasıl düşlüyoruz? Yerli filmlerin kurmaca dünyasında demokrasi. Türk Sinemasında Demokrasi Kavramının Gelişmesi içinde (74-132). Ankara: Kültür Bakanlığı.

Adesokan, A. (2009). Practising 'democracy' in Nigerian dilms. African Affairs, 108(433), 599-619.

Ahıska, M. (2012). İktidar ve taşlaşma: Çoğunluk filminin düşündürdükleri. Umut Tümay Arslan (Haz.), Bir kapıdan gireceksin: Türkiye sineması üzerine denemeler içinde (219-231). İstanbul: Metis Yayınları.

Akgün, E. ve Aslan, H. (2010, Ekim). Üç özgürlük paradigması. Uluslararası Felsefe Kongresi, Uludağ Üniversitesi, Bursa. 03.03.2018 tarihinde https://www.researchgate.net/publication/270571997_Uc_ Ozgurluk_Paradigmasi adresinden edinilmiştir.

Atabek, N. (2002). Kamuoyu, medya ve demokrasi. Kurgu, 19, 223-238.

Aytaç, S. ve Öperli, N. (2010). Çoğunluk: Betonlaşan İstanbul, betonlaşan insan. Altyazı, 99, 32-35.

Aytaç, S. ve Göl, B. (2012). Emin Alper röportajı. Altyazı, 123, 30-34.

Aytekin, Ç. ve Sütcü, C. S. (2013). Sosyal medya’da demokrasi algıss: Demokrasinin renkleri üzerine fikir madenciliği araştırması. Akdeniz İletişîm, 19, 28-44.

Breton, L. (2010). Acının antropolojisi. İsmail Yerguz (Çev.). İstanbul: Sel Yayıncllık.

Brunetta, G. P. (1995). Italian cinema and the hard road towards democracy, 1945. Historical Journal of Film, Radio and Television, 15(3), 343-348.

Büte, B. (2013). Paranoyadan sessizliğin kötülügüne: Tepenin Ardı̉nda paranoya ve kötülük üzerine. Birikimdergisi.com. 01.03.2018 tarihinde http://www.birikimdergisi.com/guncel-yazilar/446/ paranoyadan-sessizligin-kotulugune-tepenin-ardi-nda-paranoya-ve-kotuluk-uzerine\#. Wu3QPaSFOUm adresinden edinilmiştir.

Çağlıyan, Ç. (2014). Tepenin Ardı̉ndaki günah keçileri. Lale Kabadayı (Haz.), Film Eleştirisi içinde (151157). İstanbul: Ayrıntı Yayınları.

Cereci, S. (2013). Medya ve demokrasi ilişkisi: Kısıtlama sorunu. Akademik Bakış, 38, 1-8.

Chomsky, N. (1993). Medya gerçeği. Abdullah Yılmaz (Çev.). İstanbul: Tümzamanlar Yayıncılık.

Çiftçi, A. (2012). Büyük bir ailedir ulus: Tepenin Ardı. Altyazı, 123, 36-38.

Deniz, K. ve Akmeşe, Z. (2015). Sinemada toplumsal eşitsizliklerin temsili: “Çoğunluk” filmi örneği. Erciyes İletişim Dergisi, 4(1), 86-96.

Doğan, M. (2012). Tarihsel gelişim sürecinde Yörükler. Sosyoloji Dergisi, 3(13), 117-132.

Edgar, A. ve Sedgwick, P. (2007). Kültürel kuramda anahtar kavramlar. Mesut Karaşahan (Çev.). İstanbul: Açılım Kitap.

Erdoğan, İ. (2012). Pozitivist metodoloji ve ötesi. Ankara: Erk Yayınları.

Foucault, M. (2012). İktidarın gözü. Işık Ergüden (Çev.). İstanbul: Ayrıntı Yayınları.

Foucault, M. (2015). Hapishanenin doğuşu. Mehmet Ali Kılıçbay (Çev.) Ankara: İmge Yayınları.

Girgus, S. B. (1998). Hollywood renaissance: The cinema of democracy in the era of Ford, Capra and Kazan. Cambridge: Cambridge University Press.

Gön, A. (2014). Tepenin Ardı: Homososyallik, aile ve erkeklik. Sinecine, 5(1), 53-74.

Gündoğdu, A. (2014). Varlığın özü: 'Tepenin Ardı’nda Emin Alper’den bir varol(ama)ma öyküsü. Sinecine, $5(1), 27-52$.

Işık, M. (2005). Medya ve demokrasi paradoksu: Medya yoluyla demokrasinin tehdit edilmesi. Selçuk İletişim, 3(4), 114-121.

Kaboğlu, İ. (2000). Bilim ve sanat özgürlüğü. Korkut Tankuter (Ed.) İnsan haklart içinde (121-134). İstanbul: Yapı Kredi Yayınları. 
Karakaşl1, K. (2012). Çoğunluk olarak az. Umut Tümay Arslan (Haz.), Bir kapıdan gireceksin: Türkiye sineması üzerine denemeler içinde (133-141). İstanbul: Metis Yayınları.

Keane, J. (2013). Democracy and media decadence. Cambridge: Cambridge University Press.

Kellner, D. (2010). Cinema wars: Hollywood film and politics in the Bush-Cheney era. West Sussex: WileyBlackwell.

Kılıç, E. (2013). Tepenin ardında daima düşman Var: Emin Alper ile söyleşi. Evrensel Kültür, 3-6.

Konuşlu, F. (2013). Tepenin bu yanı: Mekânsal bağlamda Tepenin Ardı. Altyazi.net. 01.03.2018 tarihinde http://www.altyazi.net/yazilar/tepenin-bu-yani-mekansal-baglamda-tepenin-ardi/ adresinden edinilmiştir.

Köker, L. (1994a). Demokrasi kavramı ve Türk filmleri. Türk sinemasında demokrasi kavramının gelişmesi içinde (1-14). Ankara: Kültür Bakanlığı.

Köker, L. (1994b). Sonuç: Türk filmlerinde demokrasi temaları. Türk sinemasında demokrasi kavramının gelişmesi içinde (167-174). Ankara: Kültür Bakanlığı.

Kuzu, B. (1992). Demokrasi-resmi ideoloji-sivil toplum. Ankara Üniversitesi Siyasal Bilgiler Fakültesi Dergisi, 1(47), 335-369.

McKee, A. (2003). Textual analysis: A beginner's guide. London: Sage.

Lyon, D. (2013). Gözetim çalışmaları. Ali Toprak (Çev.). İstanbul: Kalkedon Yayınları.

Oktan, A. ve Akyol, A. (2016). Metinden imgeye metinlerarası bir figür olarak arafta olmak: Babama Mektup ve Çoğunluk örnekleminde baba-oğul ilişkileri. The Journal of Academic Social Science Studies, 45, 95-112.

Onaran, O., Abisel, N., Köker, L. ve Köker, E., (1994). Türk sinemasında demokrasi kavramının gelişmesi. Ankara: Kültür Bakanlığı.

Onaran, O. (1994). Parlak 1şıktan yoksun alacakaranlığın filmleri: Türk filmleri ve demokrasi. Türk sinemasında demokrasi kavramının gelişmesi içinde (15-73). Ankara: Kültür Bakanlı̆̆1.

Öztürk, S. (2013). Türk sinema tarihinin altpolitikası (1896-1923). Selçuk İletişim, 8(1), 251-262

Paris, M. (1998). Lessons for democracy: American cinema 1942-1945. European Review of History: Revue européenne d'histoire, 5(1), 85-94.

Ryan, M. ve Kellner, D. (2010). Politik kamera: Çă̆daş Hollywood sinemasının ideolojisi ve politikası. Elif Özsayar (Çev.). İstanbul: Ayrıntı Yayınları.

Sayıcı, F. (2011). 1990 sonrası Türk sinemasında gerçekçilik. Yayımlanmamış Yüksek Lisans Tezi. Konya: Selçuk Üniversitesi Sosyal Bilimler Enstitüsü.

Susam, A. (2014). Babanın ormanında kaybolmak: Çoğunluk. Lale Kabadayı (Haz.), Film Eleştirisi içinde (141-149). İstanbul: Ayrıntı Yayınları.

Thwaites, E. (2012). Çoğunluk’taki hayalet. Umut Tümay Arslan (Haz.) Bir kapıdan gireceksin: Türkiye sineması üzerine denemeler içinde (167-177). İstanbul: Metis Yayınları.

Uygun, O. (2000). İnsan hakları kuramı. Korkut Tankuter (Ed.) İnsan hakları içinde (13-44). İstanbul: Yapı Kredi Yayınları.

Williams, R. (2016). Anahtar sözcükler. Savaş Kılıç (Çev.). İstanbul: İletişim Yayınları.

Yaşartürk, G. (2014). Çekirdek ailenin kâbusları: 2000'li yıllar Türkiye Sineması’nda çekirdek aileye değişen bakış. Maltepe Üniversitesi İletişim Fakültesi Dergisi, 1(1), 1-28.

Yener Gökşenli, E. (2013). Franco İspanyasında sinema: Edebiyat uyarlamaları ve sansür. Sinecine, 4(2), 119133.

Yüksel, E. (2013). Babalar ve oğullar: 2000’ler Türkiye sinemasında erkeklik krizi. Sinecine, 4(2), 41-67. 